\title{
Effects of Perfusion Temperature on Inflammatory Response and Outcome Following Cardiopulmonary Bypass
}

\author{
Kardiyopulmoner Bypass Isısının Inflamatuar Cevap ve Sonuçlar Üzerine Etkileri \\ Bora Farsak¹, Mehmet Öç̉, Funda Gümüş², Bahar Öç², Vedat Erentuğ ${ }^{4}$ \\ ${ }^{1}$ Department of Cardiovascular Surgery, Faculty of Medicine, Selçuk University, Konya, Turkey \\ ${ }^{2}$ Clinic of Anesthesiology and Reanimation, Bağcılar Education and Research Hospital, İstanbul, Turkey \\ ${ }^{3}$ Department of Anesthesiology and Reanimation, Faculty of Medicine, Selçuk University, Konya, Turkey \\ ${ }^{4}$ Clinic of Cardiovascular Surgery, Bağcılar Education and Research Hospital, İstanbul, Turkey
}

\begin{abstract}
Objective: To evaluate the effects of perfusion temperature on inflammatory response, and outcome in patients undergoing open heart surgery. Methods: Forty nine patients were assigned to 2 groups, group I $(n=24)$ normothermic cardiopulmonary bypass (CPB) and group II ( $n=25)$ hypothermic CPB. Blood samples were collected preoperatively and postoperatively for interleukin-6 (IL6) and high sensitive CRP (hsCRP). Concerning the variables, there were no significant preoperative differences between the groups.

Results: At the end of CPB, mean plasma levels of IL-6 was significantly lower in the normothermia group (Group 1: $34.0 \pm 14.9$ vs. Group 2: $53.0 \pm 41$.

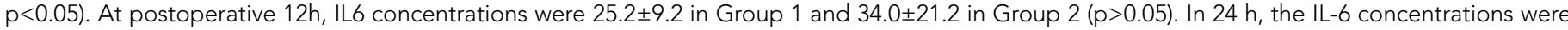
$20.4 \pm 8.1$ in Group 1 and $29.6 \pm 21.1$ in Group 2 ( $p>0.05$ ). High sensitive CRP levels were significantly higher at the end of CPB than the preoperative levels (Group 1: $16.1 \pm 3.4$ vs. Group 2: 18.5 $\pm 3.6, \mathrm{p}<0.05)$. At postoperative $12 \mathrm{~h}$ and $24 \mathrm{~h}$, hsCRP concentrations declined (Group 1: $12.8 \pm 2.6$ vs. Group 2: $13.2 \pm 2.9$ at $12 \mathrm{~h}, \mathrm{p}>0.05$ and Group 1: $12.3 \pm 2.6$ vs. Group 2: $14.2 \pm 2.8$ at $24 \mathrm{~h}, \mathrm{p}>0.05)$. Normothermic CPB resulted in a shorter CPB time; $63.1 \pm 19.1 \mathrm{~min}$. vs $82.0 \pm 19.2 \mathrm{~min}$. $(\mathrm{p}<0.01)$ and the interval up to extubation was $8.9 \pm 2.5 \mathrm{~h}$ vs. $11.6 \pm 4.6 \mathrm{~h}(\mathrm{p}<0.05)$. Blood loss was $633.1 \pm 390.4 \mathrm{ml}$ vs. $981.8 \pm 438.0 \mathrm{ml}$ $(p<0.05)$ and use of blood was $2.7 \pm 0.7$ packages vs. $4.2 \pm 0.5$ packages $(p<0.01)$ in Group 1 and Group 2 respectively, as well as the length of ICU stay $2.5 \pm 0.5$ vs. $4.0 \pm 0.6$ days, $(p<0.01)$. Length of hospital stay was significantly shorter in the normothermic group $7.2 \pm 0.5$ days vs. $8.0 \pm 0.6$ days $(p<0.01)$.
\end{abstract}

Conclusion: A strategy of normothermic CPB seems to be as safe as hypothermic CPB and is associated with a reduced inflammatory response and offers a better outcome. (JAREM 2012; 2: 10-4)

Key Words: Normothermic CPB, Hypothermic CPB, Inflamatory response, cardiopulmonary bypass, open heart surgery, CABG

\section{ÖZET}

Amaç: Açık kalp cerrahisinde perfüzyon ısısının inflamatuar cevap ve sonuçlar üzerine etkilerinin araştırılması.

Yöntemler: Toplam 49 hasta iki gruba bölünmüştür, Grup 1 ( $n=24)$ normotermik opere edilmiş, gurup 2 ( $n=25)$ hipotermik kardiyopulmoner bypass (KPB) altında opere edilmiştir. Preoperatif ve postoperatif dönemde interleukin-6 (IL6) ve high sensitive CRP (hsCRP) seviyeleri için kan örnekleri alınmıştır.

Bulgular: Kardiyopulmoner bypassın sonunda IL-6 değerleri normotermik opere edilmiş grupta hipotermik gruba oranla belirgin olarak düşük bulun-

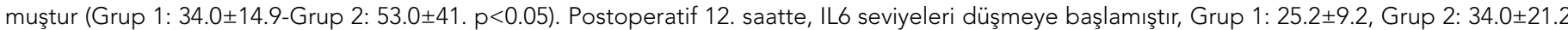
( $p>0.05$ ). Yirmi dördüncü saatte IL-6 seviyeleri Grup 1: 20.4 \pm 8.1 , Grup 2: 29.6 21.1 olarak bulunmuştur ( $p>0.05$ ). High sensitive CRP değerleri Grup 1: 16.1 \pm 3.4 , Grup 2: $18.5 \pm 3.6$ ( $p<0.05$ ). Postoperatif 12. ve 24. saatte, hsCRP seviyeleri düşmeye başlamıştır Grup 1: 12.8 2 2.6-Grup 2: $13.2 \pm 2.912$ h. saat, $p>0.05$ ve Grup 1: $12.3 \pm 2.6$-Grup 2: $14.2 \pm 2.824$.saat, p>0.05). Grup 1'de KPB ve extubasyon süreleri Grup 2'ye göre belirgin kısadır (63.1 \pm 19.1 dakika$82.0 \pm 19.2 \mathrm{~min} .(p<0.01))$ ve $(8.9 \pm 2.5$ saat $-11.6 \pm 4.6$ saat $(p<0.05)$. Grup 1 ve Grup 2 karşılaştııılığında drenaj miktarı $633.1 \pm 390.4 \mathrm{~mL}-981.8 \pm 438.0$ $\mathrm{mL}(p<0.05)$, kan kullanımı $2.7 \pm 0.7$ torba-4.2 \pm 0.5 torba ( $p<0.01)$, yoğun bakım süresi $2.5 \pm 0.5-4.0 \pm 0.6$ gün, ( $<<0.01)$ bulunmuştur. Tüm bu sonuçlar normotermik grubun hastane yatış süresini olumlu etkilemiştir $7.2 \pm 0.5$ gün-8.0 \pm 0.6 gün $(p<0.01)$.

Sonuç: Normotermik KPB stratejisi en az hipotermik KPB kadar güvenli olmasının yanı sıra inflamatuar cevabı azaltmış ve daha iyi sonuçlar vermiştir. (JAREM 2012; 2: 10-4)

Anahtar Sözcükler: Normotermik KPB, Hipotermik KPB, inflamatuar yanıt, kardiyopulmoner bypass, açık kalp cerrahisi, CABG

Received Date / Geliş Tarihi: 15.01.2012 Accepted Date / Kabul Tarihi: 18.03.2012 (C) Telif Hakkı 2012 AVES Yayınclilk Ltd. Şti. Makale metnine www.jarem.org web sayfasından ulaşılabilir. C Copyright 2012 by AVES Yayıncilik Ltd. Available on-line at www.jarem.org doi: 10.5152/jarem.2012.05 


\section{INTRODUCTION}

The deleterious effects of cardiopulmonary bypass are believed to be related to activation of neutrophils, various cytokines, complement, interleukin production, free radical generation and a wide variety of other responses collectively known as the systemic inflammatory response. This can lead to end-organ dysfunction that may affect the postoperative course of the patients and may limit surgical success (1-3). In the present investigation, a variety of surrogate markers of the inflammatory response were measured to determine the role of perfusion temperature on the magnitude and temporal nature of this response.

IL-6 is a multifunctional proinflammatory cytokine, which also plays an important role in ischemia-reperfusion injury (3-5). CRP is a member of the class of acute-phase reactants, and its levels rise dramatically during inflammatory processes. Its physiological role is to bind to phosphocholine in order to activate the complement system via the complex. The high-sensitivity CRP (hs-CRP) test measures low levels of CRP.

Cardiopulmonary bypass is a non-physiologic state associated with significant alterations in homeostatic mechanisms, hormone levels and organ perfusion which is astonishingly well tolerated during hypothermia. The response to normothermic CPB remains to be investigated. The purpose of this study is to evaluate the effects of temperature on inflammatory response and outcome during open heart surgery.

\section{METHODS}

\section{Patient groups}

Patients recruited for these prospectively controlled, randomized studies underwent elective coronary artery bypass grafting using normothermic or hypothermic CPB in Hacettepe University Faculty of Medicine, Department of Cardiovascular Surgery and Bağcılar Training and Research Hospital, Department of Cardiovascular Surgery. We enrolled 24 patients (mean age 58.0 \pm 11.2 years) in the normothermia group and 25 patients (mean age $62.6 \pm 9.9$ years) in the hypothermia group. Patients with diabetes mellitus, unstable angina, chronic obstructive lung disease and renal disease were excluded from the study. Informed consent was obtained from each patient according to the protocol of the ethics committee. Patient preoperative data were shown in Table 1.

\section{Operative techniques}

After median sternotomy and heparinization, standard cannulation techniques through the ascending aorta and right atrium were used to complete the CPB circuit. Cardiopulmonary bypass was performed with a membrane oxygenator (Edwards Vital; Edwards Lifesciences, Irvine, CA, USA). An aortic antegrade cardioplegia cannula and a retrograde coronary sinus catheter were positioned using a closed transatrial technique. The heart was arrested either antegradely or retrogradely with blood with high potassium solution $\left(\mathrm{K}^{+} 30 \mathrm{mmol} / \mathrm{L}\right)$. After cardiac arrest, retrograde low potassium blood $\left(\mathrm{K}^{+} 10 \mathrm{mmol} / \mathrm{L}\right)$ was infused every 15 minutes in Group 1 and every 20 minutes in Group 2, with the infusion pressure at the cannula tip maintained at less than $40 \mathrm{~mm} \mathrm{Hg}$. In Group 1, warm cardioplegia was infused at $37^{\circ} \mathrm{C}$ and the CPB temperature was maintained at $>34^{\circ} \mathrm{C}$. In Group 2 cold cardioplegia was infused at $4^{\circ} \mathrm{C}$ and the CPB temperature was maintained at $28^{\circ} \mathrm{C}$. The CPB pump flow was adjusted to $2.4 \mathrm{l} / \mathrm{min}$ per $\mathrm{m}^{2}$ during normothermia and to $1.8 \mathrm{l} / \mathrm{min}$ per $\mathrm{m}^{2}$ during moderate hypothermia. The mean systemic pressure was maintained at between $40-60 \mathrm{mmHg}$ with the use of vasoactive drugs in hypothermic patients and attempted to maintain it above $60 \mathrm{mmHg}$ in the normothermic patients (ephedrine, glyceroltrinitrate) where necessary. The internal mammary artery and saphenous vein grafts were used for coronary anastomosis. Heparin was neutralized with protamine hydrocloride (Protamin 1000; Roche, Istanbul, Turkey).

\section{Measurements}

Operative procedures and operative variables and intraoperative data were shown in Table 2, 3. Operative variables included the CPB time, need for vasopressors and volume during CPB. In the postoperative period, routine blood chemistry, IL6 and hsCRP parameters were analyzed: Postoperative variables; extubation time, chest tube drainage, transfusion of blood, length of ICU stay and length of hospital stay were also analyzed and shown in Table 4.

\section{Table 1. Preoperative data}

\begin{tabular}{|l|c|c|c|}
\hline Age (years) & $\begin{array}{c}\text { Group 1 } \\
(\mathbf{n = 2 4 )}\end{array}$ & $\begin{array}{c}\text { Group 2 } \\
(\mathbf{n = 2 5 )}\end{array}$ & $\begin{array}{c}\text { p } \\
\text { value }\end{array}$ \\
\hline Men/women & $58.0 \pm 11.2$ & $62.6 \pm 9.9$ & NS \\
\hline NYHA class & $17 / 7$ & $16 / 9$ & NS \\
\hline Smoking (on admission) & $2.7 \pm 0.4$ & $2.6 \pm 0.2$ & NS \\
\hline Hypertension (patient history) & $22(\%)$ & $21(\%)$ & NS \\
\hline $\begin{array}{l}\text { Hyperlipidemia (requiring } \\
\text { treatment) }\end{array}$ & $22(\%)$ & $23(\%)$ & NS \\
\hline $\begin{array}{l}\text { Obesity (> 10\% normal } \\
\text { body weight) }\end{array}$ & $6(\%)$ & $9(\%)$ & NS \\
\hline Prior myocardial infarction & $11(\%)$ & $15(\%)$ & NS \\
\hline Ejection fraction (\%) & $51 \pm 3$ & $48 \pm 4$ & NS \\
\hline NYHA: New York Heart Association & & & \\
\hline
\end{tabular}

Table 2. Operative procedures

\begin{tabular}{|l|c|c|c|}
\hline & $\begin{array}{c}\text { Group 1 } \\
(\mathbf{n = 2 4 )}\end{array}$ & $\begin{array}{c}\text { Group 2 } \\
(\mathbf{n = 2 5 )}\end{array}$ & $\begin{array}{c}\mathbf{p} \\
\text { value }\end{array}$ \\
\hline CABG & 24 & 25 & NS \\
\hline No. of grafts & $3.3 \pm 0.2$ & $3.5 \pm 0.3$ & NS \\
\hline Urgent procedures & $3(\%)$ & $2(\%)$ & NS \\
\hline CABG: coronary artery bypass grafting & & & \\
\hline
\end{tabular}

\section{Table 3. Intraoperative data and variables}

\begin{tabular}{|l|c|c|c|}
\hline & $\begin{array}{c}\text { Group 1 } \\
(\mathbf{n = 2 4 )}\end{array}$ & $\begin{array}{c}\text { Group 2 } \\
(\mathbf{n = 2 5 )}\end{array}$ & $\begin{array}{c}\mathbf{p} \\
\text { value }\end{array}$ \\
\hline Ephedrine $(\mathrm{mg})$ & $10.3 \pm 3.1$ & $33.1 \pm 4.1$ & $\mathrm{p}<0.05$ \\
\hline $\begin{array}{l}\text { No. of patients with } \\
\text { vasopressors }\end{array}$ & $12(50 \%)$ & $14(56 \%)$ & NS \\
\hline CPB time (min) & $63.1 \pm 19.1$ & $82.0 \pm 19.2$ & $p<0.01$ \\
\hline Cross-clamp time (min) & $50.0 \pm 15.0$ & $46.6 \pm 15.2$ & NS \\
\hline
\end{tabular}




\section{Sample Collection and Laboratory Assays}

Venopuncture was performed in the morning on the patients, all of whom had been fasting for $>12$ hours. Samples were also collected at the end of the CPB, 12 and $24 \mathrm{~h}$ postoperatively. Platelet-poor plasma fractions were obtained by centrifugation at $4^{\circ} \mathrm{C}$ for 20 minutes at 4000g, and soluble IL-6 was measured by an enzyme-linked immunosorbant assay Biosource immunoassay kit (Camarillo, CA, USA). hsCRP levels were assayed in serum samples by rate turbidimetry (Immage 800 Immunochemistry System $\mathrm{CRPH}$; Beckman Coulter, Brea, CA, USA).

\section{Statistical Analysis}

Data were expressed as means \pm the standard deviation. Unpaired t-test was used to compare data and a $p$ value less than 0.05 was considered statistically significant.

\section{RESULTS}

The patients' preoperative characteristics are shown in Table 1. To assess the differences in outcome in regard to CPB temperature, Group 1 and Group 2 were compared. In respect to preoperative variables, there were no significant differences between Groups 1 and 2.

Patients in Group 1 and Group 3 were similar with respect to the number of grafts performed and type of operation (Table 2). To maintain defined systemic pressure during CPB, the hypothermic patients (group II) needed significantly higher doses of ephedrine $\mathrm{HCL}(10.3 \pm 3.1 \mathrm{vs} 33.1 \pm 4.1 \mathrm{mg}, \mathrm{p}<0.05)$. However, there were no differences in regard to the total number of patients who needed vasopressors during CPB (normothermic 12/24, 50\%; hypothermic 14/25, 56\%; NS). Cardiopulmonary bypass time was significantly shorter in the normothermic group $(63.1 \pm 19.1 \mathrm{~min}$ vs $82.0 \pm 19.2$ min. $p<0.01)$ with similar cross-clamp times in the two groups (normothermic $50.0 \pm 15.0 \mathrm{~min}$ vs. hypothermic $46.6 \pm 15.2 \mathrm{~min}$, NS) (Table 3). The postoperative extubation time was significantly shorter after normothermic CBP $(8.9 \pm 2.5 \mathrm{~h}$ vs. $11.6 \pm 4.6 \mathrm{~h}, \mathrm{p}<0.05)$, as well as the length of ICU stay $(2.5 \pm 0.5$ days vs. $4.0 \pm 0.6$ days, $\mathrm{p}<0.01)$, total amount of chest tube drainage $(633.1 \pm 390.4 \mathrm{ml} \mathrm{vs}$. $981.8 \pm 438.0 \mathrm{ml}, \mathrm{p}<0.05)$ and blood requirements $(2.7 \pm 0.7$ packages vs. $4.2 \pm 0.5$ packages, $p<0.01)$. All these results affected the length of hospital stay, which was significantly shorter in the normothermia group 7.2 \pm 0.5 days vs. $8.0 \pm 0.6$ days $(p<0.01)$ (Table 4).

Preoperative IL6 and hsCRP levels did not show any difference between the groups. In samples taken at the end of CPB, both IL6 and hsCRP levels were significantly higher than the preoperative values (Tables 5 and 6). For IL6, this difference was significant (Group 1: $34.0 \pm 14.9$ vs. Group 2: $53.0 \pm 41.6, p<0.05$ ). At postoperative $12 \mathrm{~h}$, the concentrations declined in both groups but, although it was lower in group I, it was not statistically significant (Group 1: $25.2 \pm 9.2$ vs. Group 2: $34.0 \pm 21.2 p>0.05$ ). IAt $24 h$, as shown in Figure 1, the levels continued to decline but this also was not statistically significant (Group 1: $20.4 \pm 8.1$ vs. Group 2: 29.6 $\pm 21.1 \mathrm{p}>0.05$ ) (Table 5).

As in IL6, hsCRP levels were significantly higher than the preoperative values at the end of CPB and this difference was significant between the groups (Group 1: $16.1 \pm 3.4$ vs. Group 2: $18.5 \pm 3.6$ $\mathrm{p}<0.05)$. At postoperative $12 \mathrm{~h}$ and $24 \mathrm{~h}$, hsCRP concentrations declined, (Figure 2) but they did not show any difference or statistical significance between the groups (Group 1: 12.8 \pm 2.6 vs. Group 2: $13.2 \pm 2.9$ at $12 \mathrm{~h}, \mathrm{p}>0.05$ and Group 1: Group 1: $12.3 \pm 2.6$ vs. Group 2: $14.2 \pm 2.8$ at 24 h, p>0.05), (Table 6).
Table 4. Postoperative variables

\begin{tabular}{|l|c|c|c|}
\hline & $\begin{array}{c}\text { Group 1 } \\
(\mathbf{n = 2 4 )}\end{array}$ & $\begin{array}{c}\text { Group 2 } \\
(\mathbf{n = 2 5 )}\end{array}$ & $\begin{array}{c}\text { p } \\
\text { value }\end{array}$ \\
\hline Extubation time $(\mathrm{h})$ & $8.9 \pm 2.5$ & $11.6 \pm 4.6 \mathrm{~h}$ & $\mathrm{p}<0.05$ \\
\hline ICU stay (day) & $2.5 \pm 0.5$ & $4.0 \pm 0.6$ & $\mathrm{p}<0.01$ \\
\hline Chest tube drainage $(\mathrm{ml})$ & $633.1 \pm 390.4$ & $981.8 \pm 438.0$ & $\mathrm{p}<0.05$ \\
\hline Blood (units) & $2.7 \pm 0.7$ & $4.2 \pm 0.5$ & $\mathrm{p}<0.01$ \\
\hline Hospital stay (days) & $7.2 \pm 0.5$ & $8.0 \pm 0.6$ & $\mathrm{p}<0.01$ \\
\hline
\end{tabular}

\section{Table 5. IL-6 levels}

\begin{tabular}{|l|c|c|l|}
\hline & Group 1 & Group 2 & p value \\
\hline Preoperative & $6.8 \pm 3.3$ & $6.2 \pm 3.0$ & $p>0.05$ \\
\hline After CPB & $34.0 \pm 14.9$ & $53.0 \pm 41.6$ & $p<0.05$ \\
\hline $12 \mathrm{~h}$ & $25.2 \pm 9.2$ & $34.0 \pm 21.2$ & $\mathrm{p}>0.05$ \\
\hline $24 \mathrm{~h}$ & $20.4 \pm 8.1$ & $29.6 \pm 21.1$ & $\mathrm{p}>0.05$ \\
\hline
\end{tabular}

Table 6. hsCRP levels

\begin{tabular}{|l|c|c|c|}
\hline & Group 1 & Group 2 & p value \\
\hline Preoperative & $0.47 \pm 0.27$ & $0.40 \pm 0.24$ & $\mathrm{p}>0.05$ \\
\hline After CPB & $16.1 \pm 3.4$ & $18.5 \pm 3.6$ & $\mathrm{p}<0.05$ \\
\hline $12 \mathrm{~h}$ & $12.8 \pm 2.6$ & $13.2 \pm 2.9$ & $\mathrm{p}>0.05$ \\
\hline $24 \mathrm{~h}$ & $12.3 \pm 2.6$ & $14.2 \pm 2.8$ & $\mathrm{p}>0.05$ \\
\hline
\end{tabular}

\section{DISCUSSION}

The inflammatory response that accompanies open heart surgery is multifactorial (6). The foreign surfaces in the heart-lung machine, surgical trauma, anesthesia, and deviation from normal organ perfusion are important factors causing inflammatory activation $(7,8)$. It has also been suggested that the perfusion temperature may influence the inflammatory response and outcome (9). The influence of temperature during CPB on the incidence and severity of these injuries has not yet been established. There are several theoretical objections to warm CPB: (a) enzymatic reactions are temperature dependent. This may result in an extended cellular and humoral activation during $C P B$, (b) side effects due to nonhomogeneous organ perfusion may be more evident in norrnothermia because of reduced tolerance to ischemia, (c) higher blood flow rates during CPB lead to additional blood trauma (higher shear stress) $(10,11)$. Our study could not demonstrate any important adverse effects of warm CPB. Inflammatory response is much better in normothermia.

Normothermia may have reasonably been expected to produce an exaggeration of the inflammatory response to bypass because biochemical pathways are optimal at normal body temperature. However, the results of this study and others suggest the opposite $(10,12)$. Both IL6 and hsCRP levels showed a rapid increase at the end of CPB and in both IL6 and hsCRP this increase was significantly low in Group 1, showing an attenuated inflammatory response to normothermia. At postoperative $12 \mathrm{~h}$ and $24 \mathrm{~h}$, all the concentrations declined but they did not show a major difference or statistical significance $(p>0.05)$. The literature remains confusing 


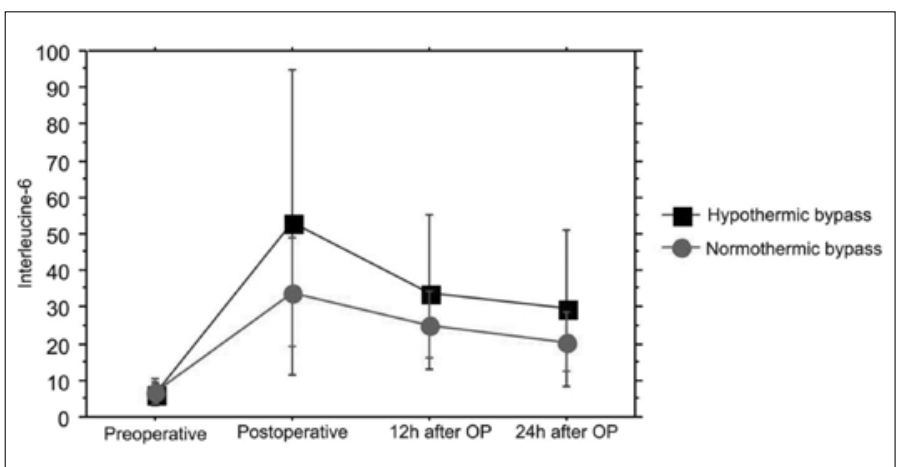

Figure 1. IL6 levels

with regard to the effects of perfusion temperature on the activity of the inflammatory response and even less is known about the clinical sequelae of these responses. Inconsistencies in definitions of normothermic bypass $\left(35-37^{\circ} \mathrm{C}\right)$ only perpetuate the controversy. In a clinical study by Menasche and associates (13), normothermic bypass $\left(35-37^{\circ} \mathrm{C}\right)$ was associated with significantly elevated levels of IL-1 $\beta$ compared to hypothermic bypass $\left(28-30^{\circ} \mathrm{C}\right)$. The incidence of vasodilatation, presumed to result from the presence of these mediators, was two-fold higher in the normothermic group, necessitating increased use of vasopressors (14). Steroid pre-treatment may prevent the vasodilatation associated with normothermic cardiopulmonary bypass by inhibition of IL-6 release (15). In contrast to these, in our study the total amount of vasopressors were higher in Group 2.

IL-6 concentrations have been shown to be much higher in patients undergoing heart transplantation, in which the duration of myocardial ischemia was much longer than in those undergoing coronary revascularization (16). There is evidence linking this cytokine to the pathogenesis of reperfusion injury, the post perfusion syndrome and the adult respiratory distress syndrome (1719). While all the studies mentioned above have provided some insight into the effects of normothermic bypass upon the inflammatory response, the practical significance with regard to end organ dysfunction still requires further evaluation. Of interest would be the effects of normothermic bypass on the systemic response in higher risk patients and those enduring long aortic cross clamp and cardiopulmonary bypass times $(12,16,20)$. Also, normothermic CPB resulted in a shorter extracorporeal perfusion time and, postoperative course with a shorter extubation time, less bleeding and shorter ICU stay $(21,22)$. Although not expressed herein; when we looked at our results on a patient basis, patients with a longer CPB time and longer aortic cross-clamp times had enhanced inflammation involving raised levels of interleukin-6 and hsCRP. This may need further investigation.

The short postoperative extubation time may reflect superior pulmonary function and/or improved hemodynamic stability after normothermic CPB, which could be explained by the attenuated inflammatory response. Similar results have been reported by several authors $(23,24)$. In a large observational study involving 2817 patients, Singh et al. (23) found no evidence of important side effects due to normothermic CPB.

Also, bleeding and blood transfusion were reduced with normothermia in this study, which was correlated with the study of others. This revealed that the normothermic heart surgery is as safe

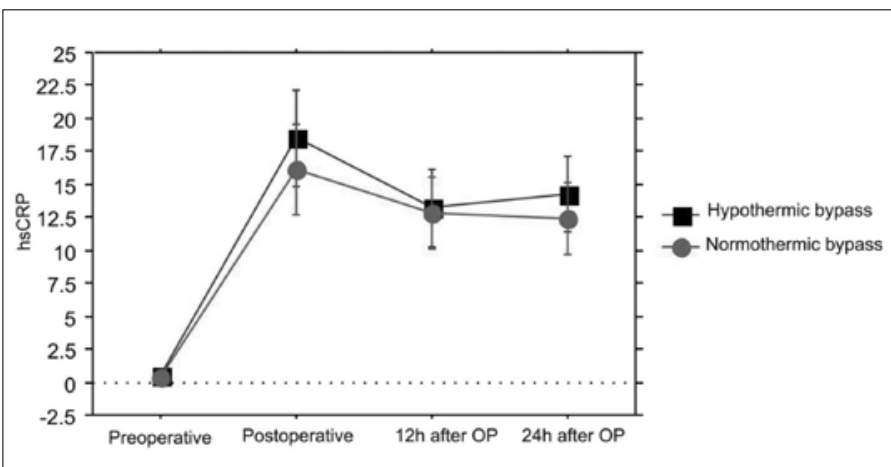

Figure 2. hsCRP levels

as hypothermic surgery, and associated with a reduced risk of allogeneic blood transfusion $(10,21,22)$. This could be due to shorter CPB times and relatively less blood trauma.

The concept that normothermia may be associated with an exaggerated inflammatory response to bypass was therefore not demonstrated in this study. One possible reason may be that clearance of these markers may also have been more rapid at higher temperatures, although it is recognized that only circulating mediators can participate in end organ injury. As a result, this study suggests that, normothermic CPB provides better outcome, attenuates inflammatory response, shortens CPB time, ICU stay, decreases blood loss and usage of blood products. According to the data, although it needs further investigation, normothermic CPB seems to be a safe alternative.

Conflict of interest: No conflict of interest was declared by the authors.

\section{REFERENCES}

1. Wan S, DeSmet JM, Barvais L, Goldstein M, Vincent JL, LeClerc JL. Myocardium is a major source of proinflammatory cytokines in patients undergoing cardiopulmonary bypass. J Thorac Cardiovasc Surg 1996; 112: 806-11. [CrossRef]

2. Gu YJ, Mariani MA, van Oeveren W, Grandjean JG, Boonstra PW. Reduction of the inflammatory response in patients undergoing minimally invasive coronary artery bypass grafting. Ann Thorac Surg 1998; 65: 420-4. [CrossRef]

3. Czerny M, Baumer H, Kilo J, Lassnigg A, Hamwi A, Vukovich T, et al. Inflammatory response and myocardial injury following coronary artery bypass grafting with or without cardiopulmonary bypass. Eur J Cardiothorac Surg 2000; 17: 737-42. [CrossRef]

4. Sawa Y, Ichikawa H, Kagisaki K, Ohata T, Matsuda H. Interleukin-6 derived from hypoxic myocytes promotes neutrophilmediated reperfusion injury in myocardium. J Thorac Cardiovasc Surg 1998;116: 511-7. [CrossRef]

5. Gaudino M, Andreotti F, Zamparelli R, Di Castelnuovo A, Nasso G, Burzotta F, et al. The $-174 \mathrm{G} / \mathrm{C}$ interleukin-6 polymorphism influences postoperative interleukin- 6 levels and postoperative atrial fibrillation. Is atrial fibrillation an inflammatory complication? Circulation 2003; 108: 195-9. [CrossRef]

6. Alcaraz AJ, Manzano L, Sancho L, Vigil MD, Esquivel F, Maroto E, et al. Different proinflammatory cytokine serum pattern in neonate patients undergoing open heart surgery. Relevance of IL-8. J Clin Immunol 2005; 25: 238-45. [CrossRef]

7. Van den Goor J, Nieuwland R, van den Brink A, van Oeveren W, Rutten $\mathrm{P}$, et al. Reduced complement activation during cardiopulmonary bypass does not affect the postoperative acute phase response Eur J Cardiothorac Surg 2004; 26: 926-31. [CrossRef] 
8. Levy JH, Tanaka KA. Inflammatory response to cardiopulmonary bypass. Ann Thorac Surg 2003; 75: S715-20. [CrossRef]

9. Speziale G, Ferroni P, Ruvolo G, Fattouch K, Pulcinelli FM, Lenti L, et al. Effect of normothermic versus hypothermic cardiopulmonary bypass on cytokine production and platelet function. J Cardiovasc Surg (Torino) 2000; 41: 819-27.

10. Birdi I, Caputo M, Underwood M, Bryan AJ, Angelini GD. The effects of cardiopulmonary bypass temperature on inflammatory response following cardiopulmonary bypass. Eur J Cardiothorac Surg 1999; 16: 540-5. [CrossRef]

11. Mollnes TE. Analysis of in vivo complement activation In: Weir's Handbook of Experimental Immunology. 5th ed. Boston: Blackwell Science; 1997. pp. 1-78.

12. Grünenfelder J, Zünd G, Schoeberlein A, Schmid ER, Schurr U, Frisullo $R$, et al. Expression of adhesion molecules and cytokines after coronary artery bypass grafting during normothermic and hypothermic cardiac arrest. Eur J Cardiothorac Surg 2000; 17: 723-8. [CrossRef]

13. Menasche P, Haydar S, Peynet J, DuBuit C, Merval R, Bloch G, et al. A potential mechanism of vasodilation after warm heart surgery. The temperature-dependent release of cytokines. J Thorac Cardiovasc Surg 1994;107:293-9.

14. Stefano G, Roderiguez M, Glass R, Cesares F, Hughes T, Bilfinger T. Hyperstimulation of leukocytes by plasma from cardiopulmonary bypass patients is diminished by morphine and interleukin 10 pretreatment. J Thorac Cardiovasc Surg 1995;36:25-30.

15. Teoh K, Bradley C, Gauldie J, Burrows H. Steroid inhibition of cytokine-mediated vasodilation after warm heart surgery. Circulation 1995; 92: 347-53. [CrossRef]

16. Wan S, Marchant A, DeSmet J, Antoine M, Ahang H, Vachiery J,et al. Human cytokine responses to cardiac transplantation and coronary artery bypass grafting. J Thorac Cardiovasc Surg 1996; 111: 469-77. [CrossRef]

17. Sekido N, Mukaida N, Harada A, Nakanishi I, Watanabe Y, Matsushima K. Prevention of lung reperfusion injury in rabbits by a monoclonal antibody against interleukin-8. Nature 1993; 365: 654-7. [CrossRef]

18. Hammerschmidt D, Stroncek D, Bowers T, Lamms-keefe C, Kurth D, Ozalins $A$, et al. Complement activation and neutropenia occurring during cardiopulmonary bypass. J Thorac Cardiovasc Surg 1981; 81: 370-7.

19. Kunkel S, Standiford T, Kasahara K, Strieder RM. Interleukin 8 (IL-8): the major neutrophil chemotactic in the lung. Exp Lung Res 1991; 17: 17-23. [CrossRef]

20. Eggum R, Ueland T, Mollnes TE, Vibeke V, Aukrust P, Fiane AE, et al. Effect of perfusion temperature on the inflammatory response during pediatric cardiac surgery. Ann Thorac Surg 2008; 85: 611-7. [CrossRef]

21. Christakis GT, Koch JP, Deemar KA, Fremes SE, Sinclair L, Chen E, et al. A randomized study of the systemic effects of warm heart surgery. Ann Thorac Surg 1992; 54: 449-57. [CrossRef]

22. Lehot JJ, Villar J, Piriz H, Philbin DM, Carry PJ, Gauquelin G, et al. Hemodynamic and hormonal responses to hypothermic and Normothermic cardiopulmonary bypass. J Cardiothorac Vasc Anesth 1992; 11: 132-9. [CrossRef]

23. Singh AK, Feng WC, Bert AA, Rotenberg FA. Warm body, cold heart surgery: clinical experience in 2817 patients. Eur J Cardio-thorac Surg 1993; 7: 225-30. [CrossRef]

24. Martin TD, Tao X, Weintraub WS, Craver JM, Guyton RA. Warm blood versus cold crystalloid cardioplegia: a casematched comparison. Circulation 1992; 86 [Suppl]:I-104. 